\title{
Assessment of variability and association for seed yield and yield attributing traits among the interspecific derivatives of greengram $x$ blackgram cross
}

\author{
S. Ragul \\ National Pulses Research Centre, Tamil Nadu Agricultural University, Vamban - 622303 \\ (Tamil Nadu), India \\ N. Manivannan* \\ National Pulses Research Centre, Tamil Nadu Agricultural University, Vamban - 622303 \\ (Tamil Nadu), India
}

\section{A. Mahalingam}

Regional Research Station, Tamil Nadu Agricultural University, Virudhachalam - 606001 (Tamil Nadu), India

${ }^{*}$ Corresponding author. Email: nm68@tnau.ac.in

\section{Article Info}

https://doi.org/10.31018/ jans.v13iSI. 2770

Received: March 22, 2021

Revised: April 17, 2021

Accepted: May 8, 2021

\section{How to Cite}

Ragul, S. et al. (2021). Assessment of variability and association for seed yield and yield attributing traits among the interspecific derivatives of greengram x blackgram cross. Journal of Applied and Natural Science, 13 (SI), 1 - 8. https:// doi.org/10.31018/jans.v13iSI.2770

\begin{abstract}
The present investigation was carried out with 24 progenies in $\mathrm{F}_{4}$ generation of interspecific cross derivatives of Vigna radiata cv. VBN $(G g) 2 \times$ Vigna mungo cv. Mash 114 to study the variability and association among the yield and the yield component traits. A set of $24 F_{4}$ progenies from the interspecific cross between greengram (VBN(Gg)2) and blackgram (Mash 114) formed the basic genetic material for the present investigation. Variability studies recorded high Phenotypic Coefficient of Variation (PCV) and Genotypic Coefficient of Variation (GCV) for the traits viz., number of branches/ plant, number of clusters/ plant, number of pods/ plant and seed yield /plant. High heritability $\left(h^{2}\right)$ along with high genetic advance as per cent of mean (GAM) were recorded for the traits, plant height, number of clusters/ plant, number of pods/ plant and seed yield/ plant. Association studies revealed that the trait number of pods/ plant alone recorded high direct positive effect on seed yield/ plant. The results indicated that high magnitude of variability was present among the interspecific progenies for these traits. The high heritability and genetic advance might be due to presence of additive gene action. Hence selection based on these traits might be effective for genetic improvement among the interspecific progenies of Vigna radiata $x$ Vigna mungo. The study indicates that the trait, number of pods / plant should be given due importance in selection programme for seed yield improvement in the interspecific progenies of greengram and blackgram.
\end{abstract}

Keywords: Association, Interspecific hybridization, Variability, Vigna, Yield traits

\section{INTRODUCTION}

Pulses are the principal source of dietary protein among vegetarians. It is an integral part of a human's daily diet because of its high protein content and good amino-acid balance. The combined balanced amino acid composition of cereals and protein blend match with the milk protein. Hence the pulses are often called lifeline of human beings. Among the pulses greengram [Vigna radiata (L.) Wilczek] is one of the most important pulse crops of South East Asian countries where is grown under varying climatic conditions extensively and it is consumed as dry seed and fresh green pods (Karuppanapandian et al., 2006). It is rich in essential amino acids especially lysine, which is deficient in most of the cereal grains. In India, greengram is being cultivated in an area of 4.26 million hectares with an annual production and productivity of 2.01 million tones and $472 \mathrm{~kg} / \mathrm{ha}$ respectively (Anonymous, 2019). Both biotic and abiotic stresses constraints the legume production. Among them diseases due to viruses are one of the major biotic causes of losses to production in the Southern Asia (llyas et al., 2009). It causes severe yield loss and a reduction in seed quality as well. $A$ 
large number of improved varieties have been developed through different breeding methods viz., pure line selection and hybridization utilizing intraspecific diversity. This has inadvertently led to narrow down the genetic base of released varieties. This indicates that immediate steps should be taken up for broadening the genetic base of greengram and to meet the future needs of the growing population. This could be achieved by reorientation of breeding strategies, coupled with thrust on interspecific hybridization.

Interspecific hybridization is one of the important tools for genetic enhancement and improvement of the crop plants. Also, to develop any interspecific lines, variability is very essential for the utilization and to critically evaluate them for better exploitation. The interspecific material obtained can be an genetic reservoir for novel genes to widen the genetic base of any crop apart from contributing to yield and its components (Pandiyan et al., 2010; Ragul et al., 2021). Various reports indicate that many related species of Vigna has desirable traits that can be utilized for greengram improvement programme. However, most of these related species remain un-utilized due to complications such as crossing barriers and linkage drag. Black gram possess nonshattering pods with synchronous maturity, more number of clusters / plant, pods with bold seeds and comparatively more resistance to Mung bean Yellow Mosaic Virus (MYMV) disease, which can be transferred to greengram via. wide hybridization.

An estimate of extent of variability available in segregating population could be of immense value to the breeder to design efficient breeding procedure for crop improvement. Hence, the success of any breeding program depends on the nature, magnitude of genetic variability and the extent of association between various yield-contributing characters. Further, genetic improvement of quantitative traits can be achieved through a clear understanding of nature and amount of variability present in the breeding material and the extent to which desirable traits are heritable. Therefore, information on genetic parameters such as variance, coefficient of variation and heritability of desirable traits will help the breeder to evolve superior cultivars (Bello et al., 2012). Yield is the most important and complex trait governed by polygenes and influenced by many physiological processes within the plant as well as by the environmental factors. Selection based on yield performance may provide biased conclusions. The extent and nature of association between yield and its components traits assume special significance and help breeders to ascertain the real components of yield and effective basis of phenotypic selection (Rao et al., 2006). The path coefficient analysis elucidates nature of association prevailed between yield and its attributes. It also reveals the magnitude of contribution made by different plant traits towards yield, thereby imparting confidence in selection of important yield attributes (Singh and Singh, 1998). Path coefficient analysis provides an effective means of finding out direct and indirect causes of association. So, correlation coefficient aided by path coefficient is a powerful tool to study the character association. Hence the present study was focused on assessing the extent of variation and association for the yield and yield attributing traits among the interspecific derivatives of greengram and blackgram.

\section{MATERIALS AND METHODS}

A set of $24 \mathrm{~F}_{4}$ progenies from the interspecific cross between greengram $(\mathrm{VBN}(\mathrm{Gg}) 2)$ and black gram (Mash 114) formed the basic genetic material for the present investigation. The experiment was conducted at National Pulses Research center (NPRC), Tamil Nadu Agricultural University, Vamban during Kharif 2017. All the 24 interspecific progenies were evaluated as per the standard plant production procedures with standard spacing of $10 \mathrm{~cm}$ (plant to plant) and $30 \mathrm{~cm}$ (row to row) was adopted. Recommended package of practices were followed. Nine quantitative traits viz. plant height $(\mathrm{cm})$, number of branches / plant, number of clusters / plant, number of pods / cluster, number of pods / plant, pod length $(\mathrm{cm})$, number of seeds / pod, 100- seed weight $(\mathrm{g})$ and seed yield / plant $(\mathrm{g})$ were recorded on each individual plants of $24 \mathrm{~F}_{4}$ progenies. Various genetic parameters like Phenotypic Coefficient of Variation (PCV), Genotypic Coefficient of Variation (GCV), heritability and genetic advance as per cent of mean (GAM) were evaluated by adopting the methods given by Johnson et al. (1955). Simple correlation between seed yield as well as its component traits and among themselves were worked out as per the procedure suggested by Johnson et al. (1955). Path coefficient analysis was carried out based on the method suggested by Dewey and Lu (1959). Data were subjected to statistical analysis viz. correlation and path analysis was performed as per standard procedures using software TNAUSTAT statistical package (Manivannan, 2014).

\section{RESULTS AND DISCUSSION}

\section{Variability studies}

The progenies in $\mathrm{F}_{4}$ generation obtained from the interspecific cross between the parents $\operatorname{VBN}(\mathrm{Gg}) 2$ and Mash 114 recorded enormous variations for plant height $(\mathrm{cm})$, number of branches / plant, number of clusters / plant, seed lusture and seed yield / plant (g). The variations are shown in the Fig. $1 \& 2$. PCV and GCV are very essential in understanding the nature and magnitude of variability present in the population that are due to the genetic and non-genetic cause. As GCV provides the total amount of heritable portion in 

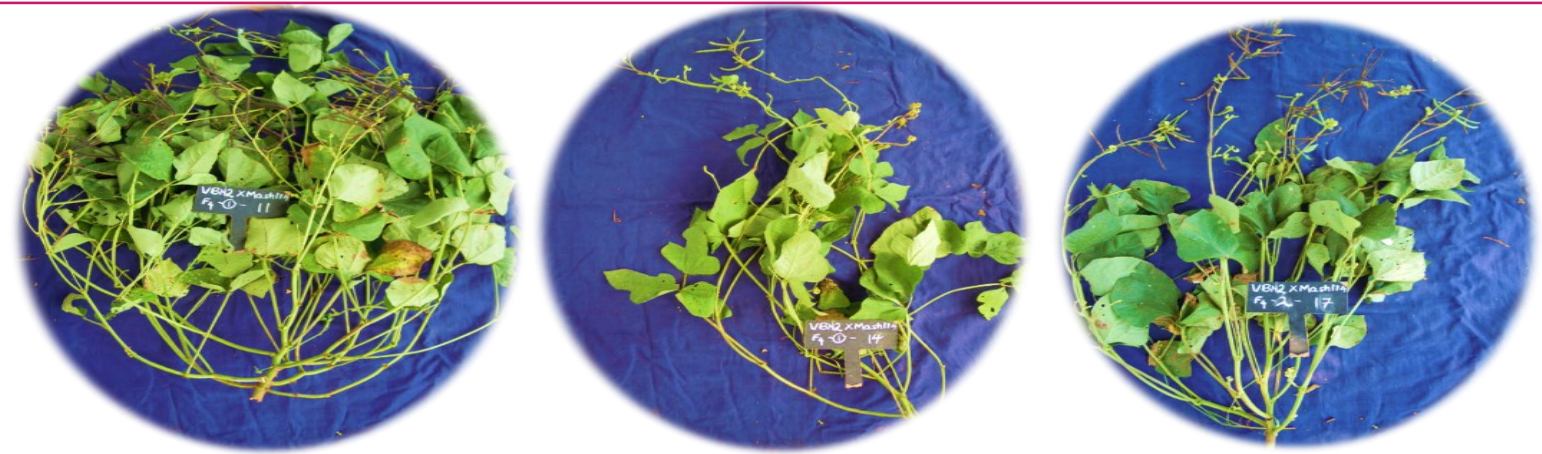

Fig. 1. Variation in branching pattern among $F_{4}$ generation interspecific progenies of greengram and blackgram.

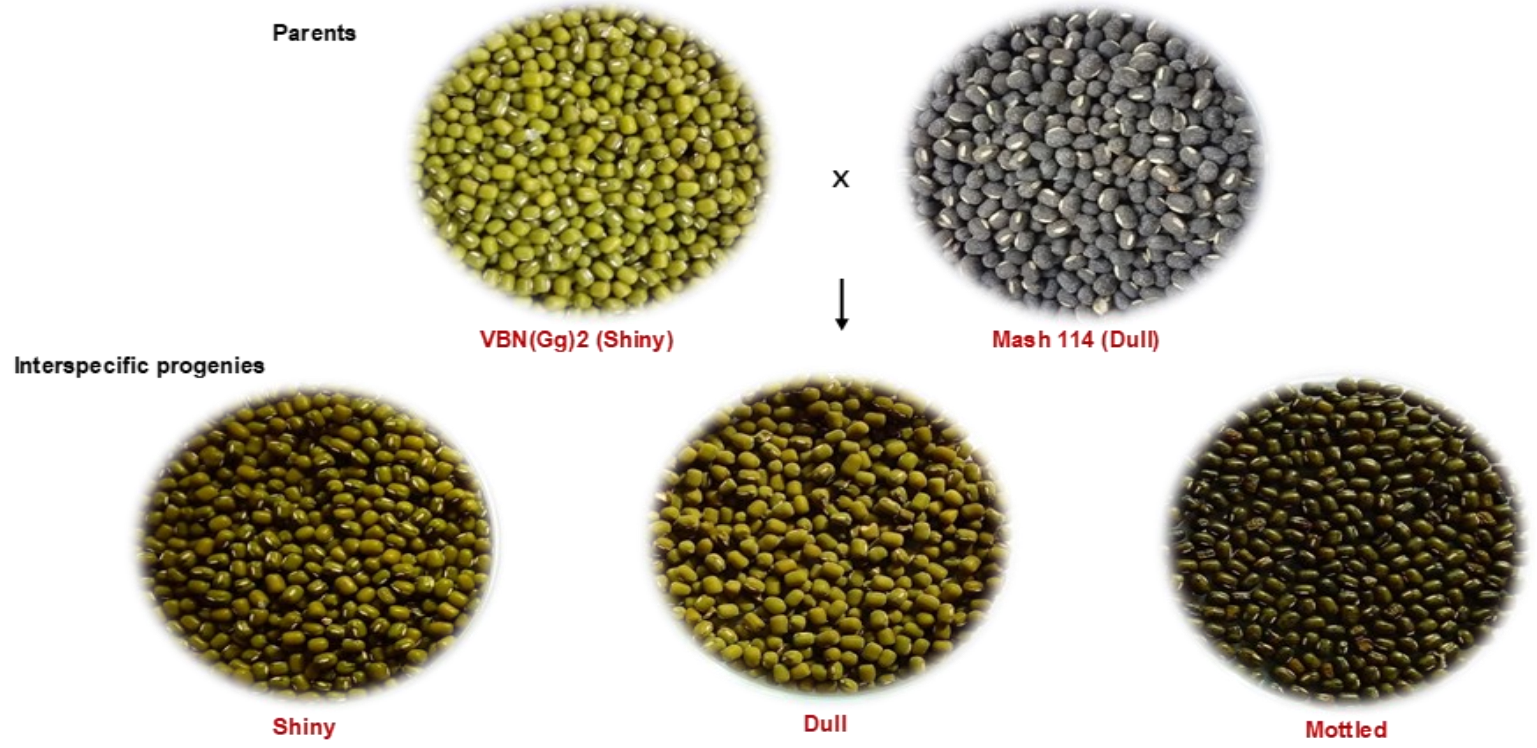

Fig. 2. Variation in seed lusture among $F_{4}$ generation interspecific progenies of greengram and blackgram.

the total variability, PCV includes the environmental variability also. All the $F_{4}$ generation progenies of the interspecific cross Vigna radiata $x$ Vigna mungo exhibited higher PCV than the GCV for all the traits under study (Table 1).

High PCV and GCV values for the plant height were recorded by the progenies 3-4, 3-5, 3-20, 3-21 and 331. Remaining progenies recorded moderate to low PCV and GCV. All the progenies in the $F_{4}$ generation recorded high PCV and GCV for the trait number of branches / plant. Likewise, all the progenies recorded high PCV and GCV for the trait number of clusters / plant. High PCV and GCV values were recorded by all the progenies except the progenies (viz., 3-1, 3-13, 3$14,3-24,3-25$ and 3-31) for number of pods / cluster. High PCV along with high GCV values were recorded by all the progenies for number of pods / plant. High PCV and GCV values were recorded by the progenies 3-5, 3-22 and 3-31 for the trait pod length. The progeny 3-20 recorded for high PCV and moderate GCV values. Remaining progenies recorded Low PCV and low GCV for the trait pod length. High PCV and GCV were recorded by 3-2, 3-4, 3-5, 3-7, 3-11, 3-12, 3-14, 3-19, 3$20,3-21,3-22$ and $3-30$ for the trait number of seeds $/$ pod. Remaining progenies exhibited moderate to low level of PCV and GCV values for the trait number of seeds / pod. High PCV and GCV values were recorded by 3-2, 3-3, 3-5, 3-7, 3-9, 3-10, 3-14, 3-19, 3-20, 3-21, $3-22,3-24,3-25,3-28$ and $3-31$ for 100 - seed weight. High PCV along with moderate GCV were registered by 3-1, 3-4, 3-12, 3-16 and 3-29 for this trait. High PCV and GCV were recorded by all progenies for the trait seed yield / plant, except the progeny 3-20. The progeny 3-20 recorded high PCV and moderate GCV. Similar results were reported by Yimram et al. (2009). Among the superior progenies viz., 3-2, 3-3, 3-12, 3-13 and 3-30, all of them recorded high PCV and GCV for the trait number of branches / plant, number of clusters / plant, number of pods / plant and seed yield / plant. Progenies 3-2, 3-3, and 3-12 also showed high to moderate PCV and GCV for plant height, number of pods / cluster and pod length. Progenies 3-30 also had high to moderate PCV and GCV for number of pods / cluster, plant height, and seed yield / plant. The results emphasis that the progenies of the interspecific cross had high PCV and GCV values for all the traits studied. Similar reports of high PCV and GCV among the various populations of greengram for all the traits were 
given by (Suresh et al., 2010; Begum et al., 2013; Khaimichho et al., 2014 and Ramakrishnan et al., 2018). High levels of variability were prevalent among the progenies which might be due to interspecific hybridization. Hence selection need to be carried out for all the traits among the promising progenies.

Heritability and genetic advance as per cent of mean are essential for any population to know the magnitude of inheritance of traits and helpful in formulating the selection procedure. Selection based on these parameters rewards good results in the improvement for traits due to the presence of additive type of gene action. High heritability and along with high genetic advance as per cent of mean was recorded by the progenies such as 3-6, 3-11 and 3-19 for the trait plant height given in the Table 2. All the progenies recorded with high heritability with high genetic advance as per cent of mean for the trait number of branches / plant. High heritability with high genetic advance as per cent of mean for the trait number of clusters per plant was observed in all the progenies in the $\mathrm{F}_{4}$ generation except $3-22$ and 3-24 which showed moderate heritability with moderate genetic advance as per cent of mean.

High heritability along with high genetic advance as per cent of mean for the trait number of pods / cluster were recorded by the progenies 3-3, 3-4, 3-6, 37, 3-10, 3-12, 3-22 and 3-29. High heritability along with high genetic advance as per cent of mean for the traits number of pods / plant were recorded by all the progenies except 3-9, 3-16, 3-20, 3-21, 3-22, 3$24,3-25$ and $3-28$. High heritability with high genetic advance as per cent of mean were recorded by all the progenies for the trait pod length except 3-13, 314 and 3-25. The trait number of seeds / pod recorded high heritability with high genetic advance as per cent of mean for the progenies 3-2, 3-3, 3-4, 3-5, 3$6,3-7,3-10,3-11,3-12,3-14,3-16,3-19,3-20,3-21$ and 3-22. The trait 100- seed weight recorded high heritability along with high genetic advance as per cent of mean for the progenies of 3-1, 3-2, 3-3, 3-4, $3-5,3-7,3-9,3-10,3-12,3-14,3-16,3-19,3-21,3-$ $24,3-25,3-30$ and $3-31$. High heritability with high genetic advance as per cent of mean for the trait seed yield / plant were recorded by the all the progenies, except the progenies 3-9, 3-20, 3-22, 3-24, 325 and 3-28.

Among the superior yielding progenies $3-2,3-3,3-$ $12,3-13$ and $3-30$, high heritability along with high genetic advance as per cent of mean was recorded by all the progenies for the traits plant height, number of clusters / plant, number of pods / plant and seed yield / plant. Similar results of high heritability and high genetic advance as percent of mean was recorded in the various populations of greengram was given by (Katiyar et al., 2015; Jeberson et al., 2017 and Ramakrishnan et al., 2018) The progenies 3-2, 3-12 and 3-30 had high heritability and genetic advance as per cent of mean for the trait number of branches / plant. Among the superior yielding progenies 3-3 and 3-12 recorded high heritability along with genetic advance as per cent of mean for the trait number of pods / cluster. For the trait pod length, number of seeds / pod and 100- seed weight some of the progenies viz., 3-2, 3-3, 3-12 and 3-30 recorded high heritability along with high genetic advance as per cent of mean among the superior

Table 3. Simple correlation between single plant yield and yield component traits in the $F_{4}$ progenies of interspecific cross Vigna radiata x Vigna mungo.

\begin{tabular}{|c|c|c|c|c|c|c|c|c|c|}
\hline Characters & $\begin{array}{l}\text { Plant } \\
\text { height } \\
\text { (cm) }\end{array}$ & $\begin{array}{l}\text { No. of. } \\
\text { branch- } \\
\text { es/ plant }\end{array}$ & $\begin{array}{l}\text { No. of. } \\
\text { clusters I } \\
\text { plant }\end{array}$ & $\begin{array}{l}\text { No. of. } \\
\text { pods I } \\
\text { cluster }\end{array}$ & $\begin{array}{l}\text { No. of. } \\
\text { pods/ } \\
\text { plant }\end{array}$ & $\begin{array}{l}\text { Pod } \\
\text { length } \\
(\mathrm{cm})\end{array}$ & $\begin{array}{l}\text { No. of. } \\
\text { seeds I } \\
\text { pod }\end{array}$ & $\begin{array}{l}\text { 100-seed } \\
\text { weight } \\
\text { (g) }\end{array}$ & $\begin{array}{l}\text { Seed } \\
\text { yield/ } \\
\text { plant (g) }\end{array}$ \\
\hline $\begin{array}{l}\text { Plant Height } \\
\text { (cm) } \\
\text { No. of. }\end{array}$ & 1 & $0.10^{* *}$ & $0.19^{* *}$ & $0.25^{\star *}$ & $0.21^{* *}$ & $0.08^{*}$ & $0.22^{* *}$ & 0.02 & $0.10^{*}$ \\
\hline $\begin{array}{l}\text { Branches / } \\
\text { Plant }\end{array}$ & & 1 & $0.44^{* *}$ & $0.12^{* *}$ & $0.39^{* *}$ & 0.07 & $0.15^{* *}$ & 0.00 & $0.29^{* *}$ \\
\hline $\begin{array}{l}\text { No. of. Clus- } \\
\text { ters / Plant }\end{array}$ & & & 1 & $0.35^{* *}$ & $0.86^{* *}$ & 0.05 & $0.37^{* *}$ & 0.03 & $0.71^{* *}$ \\
\hline $\begin{array}{l}\text { No. of. Pods / } \\
\text { Cluster }\end{array}$ & & & & 1 & $0.55^{\star *}$ & 0.03 & $0.34^{* *}$ & -0.03 & $0.39^{* *}$ \\
\hline $\begin{array}{l}\text { No. of. Pods/ } \\
\text { Plant }\end{array}$ & & & & & 1 & 0.05 & $0.38^{* *}$ & 0.01 & $0.81^{* *}$ \\
\hline $\begin{array}{l}\text { Pod Length } \\
(\mathrm{cm})\end{array}$ & & & & & & 1 & $0.15^{\star *}$ & 0.00 & 0.05 \\
\hline $\begin{array}{l}\text { No. of. } \\
\text { Seeds / Pod }\end{array}$ & & & & & & & 1 & 0.07 & $0.32^{* *}$ \\
\hline $\begin{array}{l}\text { 100-seed } \\
\text { weight }(\mathrm{g})\end{array}$ & & & & & & & & 1 & 0.02 \\
\hline $\begin{array}{l}\text { Seed Yield/ } \\
\text { plant }(\mathrm{g})\end{array}$ & & & & & & & & & 1 \\
\hline
\end{tabular}

${ }^{*}$ Significant at 5\%; ** Significant at $1 \%$ 
Ragul, S. et al. / J. Appl. \& Nat. Sci. 13 (SI), 1 - 8 (2021)

Table 4. Path coefficients on seed yield in the $\mathrm{F}_{4}$ progenies of interspecific cross Vigna radiata $\mathrm{x}$ Vigna mungo.

\begin{tabular}{llllllllll}
\hline Characters & $\begin{array}{l}\text { Plant } \\
\text { height } \\
\text { (cm) }\end{array}$ & $\begin{array}{l}\text { No. of. } \\
\text { branch- } \\
\text { es/ plant }\end{array}$ & $\begin{array}{l}\text { No. of. } \\
\text { clusters } / \text { plant }\end{array}$ & $\begin{array}{l}\text { No. of. } \\
\text { pods } / \\
\text { clus- } \\
\text { ter }\end{array}$ & $\begin{array}{l}\text { No. } \\
\text { of. } \\
\text { pods/ } \\
\text { plant }\end{array}$ & $\begin{array}{l}\text { Pod } \\
\text { length } \\
\text { (cm) }\end{array}$ & $\begin{array}{l}\text { No. of. } \\
\text { seeds } \\
\text { / pod }\end{array}$ & $\begin{array}{l}\text { 100-seed } \\
\text { weight } \\
\text { (g) }\end{array}$ & $\begin{array}{l}\text { Simple cor- } \\
\text { relation on } \\
\text { Seed yield/ } \\
\text { plant (g) }\end{array}$ \\
\hline $\begin{array}{l}\text { Plant Height } \\
\text { (cm) }\end{array}$ & -0.069 & -0.005 & 0.005 & -0.019 & 0.176 & 0.001 & 0.007 & 0.000 & $0.095^{*}$ \\
$\begin{array}{l}\text { No. of. } \\
\text { Branches / }\end{array}$ & -0.007 & -0.048 & 0.012 & -0.009 & 0.334 & 0.001 & 0.004 & 0.000 & $0.287^{* *}$ \\
$\begin{array}{l}\text { Plant } \\
\begin{array}{l}\text { No. of. Clus- } \\
\text { ters / Plant }\end{array}\end{array}$ & -0.013 & -0.021 & 0.027 & -0.026 & 0.734 & 0.001 & 0.011 & 0.000 & $0.712^{* *}$ \\
$\begin{array}{l}\text { No. of. Pods / } \\
\text { Cluster }\end{array}$ & -0.018 & -0.006 & 0.009 & -0.074 & 0.471 & 0.000 & 0.010 & -0.000 & $0.393^{* *}$ \\
$\begin{array}{l}\text { No. of. Pods/ } \\
\text { Plant }\end{array}$ & -0.014 & -0.019 & 0.023 & -0.041 & 0.852 & 0.001 & 0.011 & 0.000 & $0.812^{* *}$ \\
$\begin{array}{l}\text { Pod Length } \\
\text { (cm) }\end{array}$ & -0.005 & -0.003 & 0.001 & -0.002 & 0.041 & 0.011 & 0.005 & 0.000 & 0.047 \\
$\begin{array}{l}\text { No. of. } \\
\text { Seeds / Pod }\end{array}$ & -0.015 & -0.007 & 0.010 & -0.025 & 0.325 & 0.002 & 0.030 & 0.001 & $0.320^{* *}$ \\
$\begin{array}{l}100-\text {-seed } \\
\text { weight (g) }\end{array}$ & -0.002 & -0.000 & 0.001 & 0.002 & 0.008 & 0.00 & 0.002 & 0.008 & 0.019 \\
\hline
\end{tabular}

Residual effect - 0.37 ; *Significant at $5 \%$; ** Significant at $1 \%$

progenies. High heritability in the progenies indicates that these traits were less influenced by the environmental effects. High heritability with high genetic advance as per cent of mean showed the presence of additive gene action. Hence selection can be carried with greater efficiency in these promising progenies.

\section{Correlation coefficient analysis}

Simple correlations coefficients between seed yield / plant and its component traits and inter relationships among the different traits are presented in Table 3. Seed yield / plant expressed significant and positive association with the traits studied viz., plant height, number of branches / plant, number of clusters / plant, number of pods / cluster, number of pods / plant and number of seeds / pod except pod length and 100seed weight. This result was in accordance with the findings of Marappa (2008) and Kumar et al. (2013) among various populations of greengram. In the present investigation, number of branches / plant had significant and positive correlation with number of clusters / plant, number of pods / cluster, number of pods / plant and number of seeds / pod. This was supported by Rao et al. (2006). Number of clusters / plant expressed significant and positive relationship with number of pods / cluster, number of pods / plant and number of seeds / pod. Number of pods / cluster had significant positive association with number of pods / plant and number of seeds / pod as in the reports of Singh et al. (2009). Number of pods / plant expressed significant positive association with number of seeds / pod alone. Pod length had significant and positive association with number of seeds / pod. The estimates of correlation coefficients revealed only the relationship between yield components. The association among traits are may be due to other components. In order to get direct and indirect effect, path coefficient analysis on seed yield / plant was carried out. The results are presented in Table 4. The residual effect (0.37) indicated that most of the characters were accounted for path analysis on yield.

\section{Path coefficient analysis}

In the present study, path analysis revealed that number of pods / plant alone depicted high direct effect on seed yield / plant. All other traits recorded minimum direct effect on seed yield / plant. Present result is in accordance with findings of Hakim (2016). These results clearly showed that major importance needed to be given for number of pods / plant for the improvement of greengram through interspecific hybridization. Further number of pods / clusters recorded negative direct effect on seed yield / plant. Based on the results of present investigation, it can be concluded that number of pods / plant alone recorded significant and positive association with seed yield / plant. This trait alone recorded high direct effect on seed yield / plant. Hence number of pods / plant can be given top most priority while framing a selection strategy for the seed yield improvement of interspecific derivatives of Vigna radiata $\mathrm{x}$ Vigna mungo.

\section{Conclusion}

The present results demonstrate that wide hybridization is an important tool in crop improvement. In the present 
investigation, among the interspecific progenies high PCV and GCV was identified for all traits studied. And also high heritability and high genetic advance as percent of mean identified for all the traits studied. Based on the association studies the most priority has to be given for the number of pods / plant than the other traits. Hence selection based on these traits might be effective for genetic improvement among the interspecific progenies of Vigna radiata $\mathrm{x}$ Vigna mungo. The study indicates that the trait, number of pods/plant should be given due importance in selection programme for seed yield improvement in the interspecific progenies of greengram and blackgram.

\section{ACKNOWLEDGEMENTS}

Authors are acknowledging the help rendered by $\mathrm{Mr}$. Arul Doss, Agricultural Supervisor, National Pulses Research Centre, Vamban, Pudukottai, Tamil Nadu, in the field trials.

\section{Conflict of interest}

The authors declare that they have no conflict of interest.

\section{REFERENCES}

1. Anonymous, (2019). AICRP on MULLaRP: Project Coordinator Report- All India Coordinated Research Project on MULLaRP. ICAR- Indian Institute of Pulses Research, Kanpur-208204, Uttar Pradesh, India., Pp-46

2. Begum, S., Noor. M., Ur Rahman. H., Hassan. G., Ullah. H. \& Ali. F. (2013). Heritability estimates and correlations among flowering and yield related traits in mung bean genotypes. British Journal of Applied Science \& Technology, 3(3), 472.

3. Bello, O.B., Ige, S.A., Azeez, M.A., Afolabi, M.S., Abdulmaliq, S.Y. \& Mahamood. J. (2012). Heritability and genetic advance for grain yield and its component character in Maize (Zea mays L.), International Journal of Plant Research, 2, 138-145.

4. Dewey, D. R. \& Lu. K. H. (1959), A correlation and pathcoefficient analysis of components of crested wheatgrass seed production Agronomy Journal, 51(9), 515-518

5. Hakim, L. (2016), Variability and correlation of agronomic characters of mungbean germplasm and their utilization for variety improvement program. Indonesian Journal of Agricultural Science, 9(1), 24-28. DOI: 10.21082/ijas.v9 $\mathrm{n} 1.2008 .24-28$

6. Ilyas, M., Qazi. J., Mansoor, S. \& Briddon, R.W. (2009), Molecular characterisation and infectivity of a "Legumovirus" (genus Begomovirus: family Geminiviridae) infecting the leguminous weed Rhynchosia minima in Pakistan. Virus Research, 145(2), 279-284.

7. Jeberson, M. S., Shashidhar. K.S., Wani, S.H. \& Singh, A.K. (2017), Multivariate analysis in Mungbean (Vigna radiata $\mathrm{L}$. Wilczek) for genetic diversity under acidic soils of Manipur, India. Int. J. Curr. Microbiol. App. Sci., 6(7),
760-769.

8. Johnson, H. W., Robinson. H. \& Comstock. R. (1955), Estimates of genetic and environmental variability in soybeans 1. Agronomy Journal, 47(7), 314-318.

9. Karuppanapandian, T., Karuppudurai. T., Sinha. P.B., Kamarul. H. \& Manoharan. K. (2006), Genetic diversity in green gram [Vigna radiata (L.)] landraces analyzed by using random amplified polymorphic DNA (RAPD). African Journal of Biotechnology, 5(13), 1214-1219

10. Katiyar, M., Kumar. S. \& Kumar. N. (2015), Path analysis, association and variation of grain yield attributes in mungbean (Vigna radiata L. Wilczek). International Journal, 3 (6), 2410-2413.

11. Khaimichho, E., Hijam. L., Sarkar. K. \& Mukherjee. S. (2014), Genetic control and character association estimates of yield and yoeld attributing traits in some mungbean genotypes. Journal of Crop and Weed, 10(2), 82-88.

12. Kumar, K., Prasad. Y., Mishra. S., Pandey. S. \& Kumar. R. (2013), Study on genetic variability, correlation and path analysis with grain yield and yield attributing traits in green gram [Vigna Radiata (L) Wilczek]. The Bioscan, 8 (4), 1551-1555.

13. Manivannan, N. (2014). TNAUSTAT-statistical package. Retrieved from https://sites.google.com/site/tnaustat.

14. Marappa, N. (2008), Linex tester analysis in mungbean [Vigna radiata (L.) Wilczek]. Asian Journal of Bio Science, 3(2), 289-294.

15. Pandiyan, M., Senthil. N., Ramamoorthi. N., Muthiah. A., Tomooka. N., Duncan. V. \& Jayaraj. T. (2010), Interspecific hybridization of Vigna radiata $\times 13$ wild Vigna species for developing MYMV donar. Electronic Journal of Plant Breeding, 1(4), 600-610.

16. Ragul, S., Manivannan, N. \& Mahalingam, A. (2021). Introgression of Vigna mungo genome into Vigna radiata towards the broadening of genetic base for MYMV Resistance and yield attributes. Legume Research, 44(2), 170-174. DOI: 10.18805/LR-4107

17. Ramakrishnan, C. D., Savithramma. D. \& Vijayabharathi. A. (2018), Studies on genetic variability, correlation and path analysis for yield and yield related traits in greengram [Vigna radiata (L.) Wilczek]. Int. J. Curr. Microbiol. App. Sci., 7(3), 2753-2761. DOI: https://doi.org/10.20546/ ijcmas.2018.703.318

18. Rao, C. M., Rao. Y. K. \& Reddy. M. (2006), Evaluation of mungbean germplasm for yield and yield components. Legume Research-An International Journal, 29(1), 73-75.

19. Singh, A., Singh. S., Sirohi. A. \& Yadav. R. (2009), Genetic variability and correlation studies in green gram (Vigna radiata L. Wilczek). Progressive Agriculture, 9(1), 59-62.

20. Singh, B. B. \& Singh. D.P. (1998), Variation for yield and yield components in the early segregating generations of a wide cross between mungbean and urdbean. The Indian Journal of Genetics and Plant Breeding, 58(1), 113-115.

21. Suresh, S., Jebaraj. S., Hepziba. S. J. \& Theradimani. M. (2010), Research note genetic studies in mungbean (Vigna radiata (L). Wilczek). Electronic Journal of Plant Breeding, 1(6), 1480-1482.

22. Yimram, T., Somta. P. \& Srinives. P. (2009), Genetic variation in cultivated mungbean germplasm and its implication in breeding for high yield. Field Crops Research, 112 (2-3), 260-266. 